DP --1665

DE84 000850

DP-1665

Distribution Category UC-25

\title{
STUDY OF THE $\mathrm{U}_{3} \mathrm{O}_{8}$-AI THERMITE REACTION AND STRENGTH OF REACTOR FUEL TUBES
}

by

Harold B. Peacock

\section{DISCLAIMER}

This report was prepared as an account of work sponsored by an agency of the United States Government. Neither the United States Government nor any agency thereof, nor any of their employees, makes any warranty, express or implied, or assumes any legal liability or responsibility for the accuracy, completeness, or usefulness of any information, apparatus, product, or process disclosed, or represents that its use would not infringe privately owned rights. Reference herein to any specific commercial product, process, or service by trade name, trademark, manufacturer, or otherwise does not necessarily constitute or imply its endorsement, recommendation, or favoring by the United States Government or any agency thereof. The views and opinions of authors expressed herein do not necessarily state or reflect those of the United States Government or any agency thereof.

Approved by

M. R. Buckner, Research Manager

Nuclear Engineering

Publication Date: August 1983

\section{Issued by E. I. du Pont de Nemours \& Co. Savannah River Laboratory Aiken, SC 29808}

PREPARED FOR THE U.S. DEPARTMENT OF ENERGY UNDER CONTRACT DE-AC09-76SR00001 


\section{DISCLAIMER}

This report was prepared as an account of work sponsored by an agency of the United States Government. Neither the United States Government nor any agency Thereof, nor any of their employees, makes any warranty, express or implied, or assumes any legal liability or responsibility for the accuracy, completeness, or usefulness of any information, apparatus, product, or process disclosed, or represents that its use would not infringe privately owned rights. Reference herein to any specific commercial product, process, or service by trade name, trademark, manufacturer, or otherwise does not necessarily constitute or imply its endorsement, recommendation, or favoring by the United States Government or any agency thereof. The views and opinions of authors expressed herein do not necessarily state or reflect those of the United States Government or any agency thereof. 


\section{DISCLAIMER}

Portions of this document may be illegible in electronic image products. Images are produced from the best available original document. 


\section{ABSTRACT}

Heating tests using 53 wt $\% \mathrm{U}_{3} \mathrm{O}_{8}-\mathrm{Al}$ pellets show that an exothermic reaction occurs between 875 and $1000^{\circ} \mathrm{C}$ and takes 10 to 20 seconds to reach maximum temperature. The maximum temperature is a function of particle size of the $\mathrm{U}_{3} \mathrm{O}_{8}$ with large particles exhibiting lower peak temperatures. The calculated energy release was $123 \mathrm{cal} / \mathrm{g}$ of $\mathrm{U}_{3} \mathrm{O}_{8}$-aluminum fuel. Tests using aluminum clad outer fuel tube sections gave lower peak temperatures than for pellets. No violent reactions occurred. The results are reasonably consistent with recent reported data indicating that the exothermic $\mathrm{U}_{3} \mathrm{O}_{8}-\mathrm{Al}$ reaction is not an important energy source.

The compressive and tensile strengths of $\mathrm{U}_{3} \mathrm{O}_{8}$ tubes above $660^{\circ} \mathrm{C}$ are low. In compression, sections with 2 psi average axial stress failed at $917^{\circ} \mathrm{C}$, while sections with 7 psi failed at $669^{\circ} \mathrm{C}$. Tubes with U-Al alloy cores failed at about $670^{\circ} \mathrm{C}$ with no applied load. The stresses in fuel tubes during a reactor transient may range up to several hundred psi and are less than 7 psi only in the upper part of the fuel tube. 
Introduction . . . . . . . . . . . . . . . . 7

Early Investigations . . . . . . . . . . . . . 7

Experimental Procedure . . . . . . . . . . . . . 8

Experimental Results and Discussion . . . . . . . . . . 10

Thermite Reaction . . . . . . . . . . . . 10

Pellets................... . . 10

Tube Sections . . . . . . . . . . . . . . 11

Specimen Microstructure .. . . . . . . . . . . 12

Strength of Cermet Fuel . . . . . . . . . . . . 13

Compressive Strength . . . . . . . . . . . . 13

Tensile Strength . . . . . . . . . . . . . 14

Large-Scale Test . . . . . . . . . . . . 14

Conclusions . . . . . . . . . . . . . . . 15

References ..................... 16 
1 Particle Size Distributions of Aluminum and

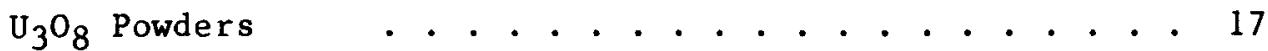

2 Tube Diameters for the Three-Tube Assembly . . . . . . 17

3. Compressive Strength of $53 \mathrm{Wt} \% \mathrm{U}_{3} \mathrm{O}_{8}$ and $45 \mathrm{Wt} \%$ U-Al Outer Tubes in Air........... 18 


\section{LIST OF FIGURES}

Page

1 Fuel Tube Cross Sections . . . . . . . . . . 19

2 Array of 19 Assembled Tube Sections.......... 20

3 Effect of $\mathrm{U}_{3} \mathrm{O}_{8}$ Particle Size on Thermal Reaction

in Rapidly Heated 53 wt $\%$ of $\mathrm{U}_{3} \mathrm{O}_{8}-\mathrm{Al}$ Pellets . . . . . 21

4 Temperature of Slowly Heated Outer Tube Section with a $53 \mathrm{Wt} \% \mathrm{U}_{3} \mathrm{O}_{8}-\mathrm{Al}$ Core . . . . . . . . . . . 22

5 Comparison Between Time-Temperature Curves for a $53 \mathrm{Wt} \% \mathrm{U}_{3} \mathrm{O}_{8}-\mathrm{Al}$ Pellet and a Tube Section

Plunged into a Preheated Furnace . . . . . . . . . . 23

6 Scanning Electron Photomicrographs at 500X

of As-Fabricated and Heated $\mathrm{U}_{3} \mathrm{O}_{8}-\mathrm{Al}$

Melt Test Specimens.............. . 24

$7 \mathrm{U}_{3} \mathrm{O}_{8}-\mathrm{Al}$ Outer Tube Section Rapidly Heated to $1375^{\circ} \mathrm{C}$. . . 25

8 Collapsed $\mathrm{U}_{3} \mathrm{O}_{8}-\mathrm{Al}$ Tubes in $1000^{\circ} \mathrm{C}$ Furnace . . . . . 26

9 Photographs ( $1 \mathrm{X}$ ) of U-Al Alloy and $\mathrm{U}_{3} \mathrm{O}_{8}-\mathrm{Al}$

Cermet Tubes from Burnout Tests . . . . . . . . . . 27 
STUDY OF THE $\mathrm{U}_{3} \mathrm{O}_{8}-\mathrm{Al}$ THERMITE REACTION

AND STRENGTH OF REACTOR FUEL TUBES

\section{INTRODUCTION}

Fuel elements for nuclear reactors have cores, sometimes called the fuel meat, which contain enriched uranium fuel completely enclosed in a compatible cladding material. Nuclear reactors operating at low temperature such as research and test reactors generally utilize aluminum or aluminum alloys for the matrix and cladding materials. Elements have been fabricated by hot rolling to form flat plates and by coextrusion ${ }^{2}$ to form rods or tubes. Prior to fabrication the core or preform is made by casting or by powder metallurgy $(P / M)$ techniques. Fuel cores containing ceramic fuel, like $\mathrm{UO}_{2}$ or $\mathrm{U}_{3} \mathrm{O}_{8}$ uniformly dispersed in a metallic matrix; are commonly called cermet elements.

Uranium-aluminum alloy cores exhibit different physical characteristics from $\mathrm{U}_{3} \mathrm{O}_{8}$-aluminum cermet cores when heated above the melting point of aluminum. The uranium-aluminum alloy simply melts along. with the cladding at approximately $660^{\circ} \mathrm{C}$ whereas the cermet element may maintain its shape at higher temperatures. Aluminum also reduces $\mathrm{U}_{3} \mathrm{O}_{8}$ above $900^{\circ} \mathrm{C}$ to form $\mathrm{UAl}_{x}$ compounds with a release of thermal energy. This exothermic reaction, sometimes referred to as a thermite reaction, may affect reactor safety analysis and charge design. The release of energy could contribute to the heat load on the reactor confinement system following a full core meltdown, and the melting or slumping behavior could alter the course of a transient accompanied by failure of safety rods.

The results in this report were obtained in 1976 during studies on the feasibility of using $\mathrm{U}_{3} \mathrm{O}_{8}$-aluminum cermet fuel for nuclear reactors. Due to reported differences in cermet behavior, the study was undertaken to-evaluate the nature of the thermite reaction for $\mathrm{U}_{3} \mathrm{O}_{8}$ produced from denitràted uranyl nitrate solution and to determine the strength of a fuel tube above the melting point of aluminum."

\section{EARLY INVESTIGATIONS}

The $\mathrm{U}_{3} \mathrm{O}_{8}$ and aluminum thermite reaction was studied by Fleming and Johnson ${ }^{3}$ in the early $1960^{\prime} s$. Results from their study were used in the safety analys is of the Oak Ridge Research Reactor. 4 
The study was made using pressed pellets of 35 to 94 wt \% Spencer Fused $\mathrm{U}_{3} \mathrm{O}_{8}$ and Alcoa 140 flake aluminum powders. Pellets were heated in an induction furnace at 60 to $70^{\circ} \mathrm{F} / \mathrm{min}$. The reaction was monitored by differential thermal analysis while the reaction products were identified, when possible, by dynamic high temperature $x$-ray diffraction and post-heating chemical analysis. The reduction of $\mathrm{U}_{3} \mathrm{O}_{8}$ was found to proceed in two steps; an early rapid reduction to $\mathrm{UO}_{2}$ and a later slow reduction of $\mathrm{UO}_{2}$ to U-Al intermetallic compounds. Similar two-step reactions were later reported by Ondracek and Patrassi ${ }^{5}$. Between $900-1100^{\circ} \mathrm{C}$, violent exothermic reactions occurred for pellets with greater than 50 wt \% oxide. The maximum temperature reached was greater than $2200^{\circ} \mathrm{C}$. A brief study of deformation under load was made at temperatures above the melting point of aluminum. The pellets exhibited some strength, which was attributed to a continuous network of $\mathrm{Al}_{2} \mathrm{O}_{3}$ or stringered $\mathrm{U}_{3} \mathrm{O}_{8}$.

The thermite reaction was 1 ater studied by Baker, et al. 6 using $\mathrm{U}_{3} \mathrm{O}_{8}$ powders having median particle sizes ranging from 12 to $149 \mu \mathrm{m}$. Cold pressed pellets of 30 to $90 \mathrm{wt} \% \mathrm{U}_{3} \mathrm{O}_{8}$ were heated in an induction furnace. Exothermic reactions were detected for oxide compositions above $30 \mathrm{wt} \% \mathrm{U}_{3} \mathrm{O}_{8}$ at both slow and rapid heating rates. Without exception, coarser powder reacted less as measured by the maximum temperatures reached. The maximum selfheating rate and temperature was about $150^{\circ} \mathrm{C} / \mathrm{sec}$ and $1750^{\circ} \mathrm{C}$, respectively, for the 75 wt $\% \mathrm{U}_{3} \mathrm{O}_{8}$ specimen. The violent reactions and peak temperatures reported by Fleming and Johns on for specimens of 85 wt $\% \mathrm{U}_{3} \mathrm{O}_{8}$ were not observed for any pellets.

Ivins and Testa ${ }^{7}$ subjected 41 wt $\% \mathrm{U}_{3} \mathrm{O}_{8}$-aluminum and uraniumaluminum alloy samples from fuel plates of the High Flux Isotope Reactor to transient fission heating in order to simulate a nuclear excursion accident in a water-cooled reactor. The samples were placed in an autoclave containing water and exposed to a burst of neutrons in the TREAT reactor. When the water temperature was less than $285^{\circ} \mathrm{C}$, the specimens lost their resemblance to plates forming a large globule(s) and some smaller particles. The fission energy was reported to be greater than $500 \mathrm{cal} / \mathrm{g}$ and the specimen temperature was greater than $1400^{\circ} \mathrm{C}$. The major reported difference between the cermet and alloy specimens was that the cermet retained its shape at higher temperatures than those required to melt aluminum. It was concluded that the thermite reaction was not an important energy source.

\section{EXPERIMENTAL PROCEDURE}

Experiments were carried out at the Savannah River Laboratory using depleted $\mathrm{U}_{3} \mathrm{O}_{8}$ and atomized commercial Alcoa 101 aluminum powders. Typical particle size distributions for the powders used 
in the tests, unless specified in the text, are shown in Table 1. The $\mathrm{U}_{3} \mathrm{O}_{8}$ powder was produced by denitrating uranyl nitrate solution to form $\mathrm{UO}_{3}$ which was then heated at $800^{\circ} \mathrm{C}$ for 6 hours in a low grade nitrogen atmosphere. The density and surface area of the oxide powder was $7.3 \mathrm{~g} / \mathrm{cc}$ and $0.2 \mathrm{~m}^{2} / \mathrm{g}$, respectively.

Cold pressed pellets and coextruded tube sections were used in the tests. The pellets allowed comparison of the experimental data with published information. Pellets 1 inch $(2.5 \mathrm{~cm})$ in height and diameter were mechanically compacted to about $85 \%$ theoretical density from blended $\mathrm{U}_{3} \mathrm{O}_{8}$ and aluminum powders. Aluminum sterate was used as a die lubricant for compaction. The cross sections of the tubes used in the experiments are shown in Figure 1 and the tube diameters are given in Table 2 .

The reaction studies were carried out in a globar furnace which had a sight glass in the door so the specimens could be observed during the tests. Specimens were placed on a fire brick and positioned near the center of the furnace. A small hole was drilled in the top of the pellets or in the side of the tubes so a Platinum vs. Platinum - $13 \%$ Rhodium thermocouple could be placed near the center of the specimens. The thermocouple lead wire was protected by ceramic beads. The temperature was recorded using a Hewlett Packard model $7064 \mathrm{~A} X-\mathrm{Y}$ recorder.

Both slow and rapid heating rates were used. For slow heating, the specimens were $\mathrm{placed}$ in the furnace at room temperature and heated in air at about $21^{\circ} \mathrm{C} /$ minute. Rapid heating was accom$\mathrm{p} 1$ ished by putting the specimen in a preheated $1300^{\circ} \mathrm{C}$ furnace. The average heating rate was calculated to be about $780^{\circ} \mathrm{C} / \mathrm{minute}$ up to the melting of aluminum.

Strength tests were made to determine the static stress needed to cause failure of outer cermet tubes under compressive and tensile loading. The compressive strength of the core was determined by heating in air 3 inch $(7.6 \mathrm{~cm})$ long tube sections with weights, ranging. from $1-1 / 2$ to $8-1 / 21 \mathrm{~b}(0.7$ to $3.9 \mathrm{~kg})$, placed on top of the specimens. The heating rate was about $21^{\circ} \mathrm{C} /$ minute. The tensile strength was determined using $5 \mathrm{ft}(1.5 \mathrm{~m})$ long outer tubes. The center section of approximately $2 \mathrm{ft}(60 \mathrm{~cm})$ was heated in air using a resistance furnace $\left(1^{\circ} \mathrm{C} / \mathrm{min}\right)$. Weights were hung from the bottom of the tube. The average compressive and tensile stresses were calculated by dividing the applied load by the nominal cross sectional area of the core.

After completing the reaction and strength studies, a large scale test was made to determine: if increasing the number of tubes affected the maximum temperature and if a larger specimen would collapse above $660^{\circ} \mathrm{C}$. For the test, 19 assembled tubes 18 inches long with 45 and 57 wt $\% \mathrm{U}_{3} \mathrm{O}_{8}$-aluminum cores were placed in a 
$1000^{\circ} \mathrm{C}$ preheated furnace. The array is shown in Figure 2. The steel band was placed loosely around the tubes to keep them from toppling while loading the furnace. The tubes were placed in a stainless steel tray to catch the molten aluminum and debris. Thermocouples were placed in the middle tube of each layer.

\section{EXPERIMENTAL RESULTS AND DISCUSSION}

\section{Thermite Reaction}

\section{Pellets}

Typical time-temperature curves for pellets containing 53 wt \% $\mathrm{U}_{3} \mathrm{O}_{8}$ with different size $\mathrm{U}_{3} \mathrm{O}_{8}$ particles are shown in Figure 3. Both the maximum temperature and the oxide particle size are indicated on the figure. Also shown is the furnace temperature near the specimens. Although the furnace was set at $1300^{\circ} \mathrm{C}$, the temperature near the samples was about $1250^{\circ} \mathrm{C}$ due to a thermal gradient.

Between 600 and $700^{\circ} \mathrm{C}$, the aluminum melted and exuded from the pellet. When the thermite reaction occurred at the ignition temperature between 900 and $1000^{\circ} \mathrm{C}$, the specimen glowed "white hot." But, no violent reactions as reported by Fleming and Johnson were observed for any of the $53 \mathrm{wt} \% \mathrm{U}_{3} \mathrm{O}_{8}$-aluminum pellets. This observation is consistent with Baker, et al. data indicating no violent reactions for 30 to 90 wt $\% \mathrm{U}_{3} \mathrm{O}_{8}$-aluminum pellets.

The pellets reached the reaction temperature in 1 to 2 minutes. After the reaction began, the peak temperature was reached in 10 to 20 seconds. The maximum self-heating rate was about $70^{\circ} \mathrm{C} / \mathrm{sec}$. After completing the reaction, the temperature of the pellet decreased, approaching the furnace temperature. Pellets were heated up to 30 minutes with no other exothermic reactions detected.

The maximum temperature of the pellets was a function of the particle size of the oxide as reported by Baker, et al. The highest temperature recorded was $1600^{\circ} \mathrm{C}$ and occurred for pellets with all fine $(<44 \mathrm{~m}) \mathrm{U}_{3} \mathrm{O}_{8}$ particles. Extrapolation of Baker's data gave a peak temperature of about $1500^{\circ} \mathrm{C}$ for a 53 wt $\%$ pellet. The measured peak temperature was $350^{\circ} \mathrm{C}$ higher than the recorded furnace temperature. Increasing the average size of the $\mathrm{U}_{3} \mathrm{O}_{8}$ particles to $64 \mathrm{~m}$ resulted in a maximum temperature of $1330^{\circ} \mathrm{C}$. The maximum temperature for pellets with the selected particle size distribution shown in Table 1 was $1400^{\circ} \mathrm{C}, 200^{\circ} \mathrm{C}$ less than for the specimen with all fine $\mathrm{U}_{3} \mathrm{O}_{8}$ particles.

The oxide particle size controls the reaction rate because the reaction begins at the uranium oxide-aluminum interface. Increasing the $\mathrm{U}_{3} \mathrm{O}_{8}$ particle size decreases the contact surface area between the reactants which reduces the rate of reaction and lowers the 
instantaneous energy release. The extent of the reaction for large particles is also affected because once reaction products form around the particle surface, further reactions between $\mathrm{U}_{3} \mathrm{O}_{8}$ and aluminum require diffusion of reacting elements through the barrier. For pellets containing the full range of oxide particle sizes, two reactions occurred and resulted most likely from differences in the $\mathrm{U}_{3} \mathrm{O}_{8}$ particle size distribution.

A test was also made by plunging a pellet with fine $\mathrm{U}_{3} \mathrm{O}_{8}$ particles into a $1000^{\circ} \mathrm{C}$ preheated furnace. The $1000^{\circ} \mathrm{C}$ temperature was considered the upper bound for thermite ignition. Upon completion of the reaction, the peak temperature attained was $1370^{\circ} \mathrm{C}, 370$ degrees above the furnace temperature. The pellets were heated to temperature by thermal energy from both the furnace and the exothermic reaction. The energy released for rapidly heated pellets with fine $\mathrm{U}_{3} \mathrm{O}_{8}$ particles appeared somewhat independent of the furnace temperature. After the exothermic reaction, pellet temperatures increased about $350^{\circ} \mathrm{C}$ above the furnace temperature at $1000^{\circ} \mathrm{C}$ and increased about $370^{\circ} \mathrm{C}$ above the furnace temperature at $1250^{\circ} \mathrm{C}$.

The energy released during the $\mathrm{U}_{3} \mathrm{O}_{8}$-aluminum reaction was estimated from temperature-time graphs to be about $123 \mathrm{cal} / \mathrm{g}$ of $\mathrm{U}_{3} \mathrm{O}_{8}-$ aluminum for 53 wt $\% \mathrm{U}_{3} \mathrm{O}_{8}$ pellets. The maximum heat released from the reaction of a $20 \mathrm{~kg} \mathrm{U} \mathrm{O}_{8}$-aluminum core, assuming no dilution by the aluminum cladding, is about the same as the cumulative decay heat from a 540 MWD fuel assembly during the first 30 seconds after shutdown.

The heat of reaction was calculated by Fleming and Johnson to be approximately $240 \mathrm{cal} / \mathrm{g}$ during the early rapid reaction. Pasto et al.8 recently reported an experimental value of $95 \mathrm{cal} / \mathrm{g}$ of fuel for 52 wt $\% \mathrm{U}_{3} \mathrm{O}_{8}$ in aluminum. The difference between the calculated and experimental heat of reaction is unknown. Pasto gave several possibilities for the difference which included effects of heating rate, particle size, and incomplete or higher temperature reactions.

It should be noted that exothermic reactions beginning at about $350^{\circ} \mathrm{C}$ have been identified between aluminum and impurities such as sodium uranate salts. 9 These low temperature reactions can release sufficient energy to initiate aluminothermic reduction of $\mathrm{U}_{3} \mathrm{O}_{8}$ but only if the impurities comprise a large fraction of the uranium feed in a uniform blend or in localized areas of a nonuniform blend.

\section{Tube Sections}

To determine the effect of the thermite reaction during overheating of reactor fuel, tests were conducted using 3 inch $(7.6 \mathrm{~cm})$ long sections of an outer tube. Both slow and rapid heating rates were used. A typical time-temperature curve for a slowly heated outer tube section with a 53 wt \% $\mathrm{U}_{3} \mathrm{O}_{8}$-aluminum core is shown 
in Figure 4. No reactions were detected up to $660^{\circ} \mathrm{C}$. At $660^{\circ} \mathrm{C}$, the aluminum cladding and the aluminum in the core melted as indicated by the almost isothermal part of the curve. After the aluminum melted, the temperature of the core again approached the furnace temperature indicated by the dotted line. At about $875^{\circ} \mathrm{C}$ an exothermic reaction started. The heating rate at this time was about $7^{\circ} \mathrm{C} / \mathrm{min}$. Between 875 and 925 , two small reactions occurred and were reproducible and consistent with Fleming's data showing that the reduction of $\mathrm{U}_{3} \mathrm{O}_{8}$ by aluminum takes place in two steps. It is also conceivable that the double reaction resulted from the particle size distribution because about $30 \%$ of the $\mathrm{U}_{3} \mathrm{O}_{8}$ particles were fines. The kinetics of the reaction were slow, requiring approximately 7 minutes for completion. The maximum increase in the temperature of the tube section was only $25^{\circ} \mathrm{C}$ above the furnace temperature. Tubular specimens have been heated slowly to $1375^{\circ} \mathrm{C}$ and show no further reactions.

The time-temperature curve for a rapidly heated outer tube section is shown in Figure 5 . The curve for a pellet having identical composition and similar oxide particle size distribution is also shown for comparison.

The peak temperature of $1290^{\circ} \mathrm{C}$ for the tube section was about $50^{\circ} \mathrm{C}$ above the furnace temperature or $110^{\circ} \mathrm{C}$ lower than for the pellet. Baker, et al., have also observed a lowering of the peak temperature for aluminum-clad fuel plates and have attributed the decrease to a dilution of the effective oxide content by the aluminum cladding. If all the aluminum cladding remained on the tube section after melting, the oxide concentration would decrease from 53 to $23 \mathrm{wt} \%$. However, some of the molten aluminum runs off the specimen at $660^{\circ} \mathrm{C}$ so that the effective concentration is between these values. Baker has shown that the peak temperature is a function of the composition and from his data, a peak temperature of $1290^{\circ} \mathrm{C}$ would imply an effective composition of about 35 wt \% $\mathrm{U}_{3} \mathrm{O}_{8}$.

\section{Specimen Microstructure}

Studies of the microstructure and reaction products were made using scanning electron microscopy and $x-r$ ay energy spectroscopy. Photomicrographs of fractured surfaces at 500X are shown in Figure 6 for an as-fabricated specimen and specimens heated slowly to 675 and $1375^{\circ} \mathrm{C}$. X-ray energy spectrometric analysis of both the asfabricated and the $675^{\circ} \mathrm{C}$ specimens showed that the microstructure is made up of discrete particles of $\mathrm{U}_{3} \mathrm{O}_{8}$ in the aluminum matrix. But, heating to $1375^{\circ} \mathrm{C}$ resulted in essentially a complete $\mathrm{U}_{3} \mathrm{O}_{8}-$ aluminum reaction. The microstructure no longer consisted of $\mathrm{U}_{3} \mathrm{O}_{8}$ particles but a uranium-aluminum phase $\left(U A l_{X}\right)$ and some residual aluminum. Small faceted particles containing aluminum, probably $\mathrm{Al}_{2} \mathrm{O}_{3}$, were also observed. 
Sturcken 10 studied the microstructure and low temperature reactions in $\mathrm{U}_{3} \mathrm{O}_{8}$-aluminum fuel elements irradiated to a maximum of $1 \times 10^{21} \mathrm{fissions} / \mathrm{cm}^{3}$ in a Savannah River reactor. During irradiation, the aluminum diffused into the $\mathrm{U}_{3} \mathrm{O}_{8}$ particles and formed $\mathrm{UAl}_{\mathrm{X}}$ compounds. The shape of 1 arge individual $\mathrm{U}_{3} \mathrm{O}_{8}$ particles remained about the same and no reactions with the cladding were observed which would have reduced the thickness significantly. Large irradiated particles were observed to contain spherical pores, most likely caused by the retention of fission gases within the particles.

\section{Strength of Cermet Fuel}

Cermet fuel elements maintain their shape above the melting point of aluminum because of the aluminum oxide or $\mathrm{U}_{3} \mathrm{O}_{8}$ network as postulated by Fleming and Johnson. The average stress to collapse the reactor fuel element is critical to the operating safety of cermet fuel in case of a core meltdown. The significance of the compressive or tensile strength depends on the manner in which the fuel is held in the reactor core and the applied load.

\section{Compressive Strength}

The average axial compressive stress to collapse an outer tube heated above the melting point of aluminum is given in Table 3 for a 53 wt \% $\mathrm{U}_{3} \mathrm{O}_{8}$-aluminum core. The compressive strength decreases from $11 \mathrm{psi}$ near $660^{\circ} \mathrm{C}$ to $2 \mathrm{psi}$ at $917^{\circ} \mathrm{C}$ which is within the thermite ignition temperature range of 900 to $1000^{\circ} \mathrm{C}$. With no applied load, the 3-inch cermet specimen did not collapse at $1375^{\circ} \mathrm{C}$, but bulged at the top as shown in Figure 7. During removal from the furnace, however, one side collapsed from movement or vibration. The aluminum from the cladding and core accumulated at the bottom of the specimen. For comparision, a 35 wt \% uranium-aluminum alloy core collapsed at $670^{\circ} \mathrm{C}$ with no applied load.

During irradiation, $\mathrm{U}_{3} \mathrm{O}_{8}$ and aluminum form $\mathrm{U}-\mathrm{Al}$ intermetallic compounds by a diffusion controlled low temperature reaction. To simulate the microstructure of an irradiated fuel tube, 53 wt \% $\mathrm{U}_{3} \mathrm{O}_{8}-\mathrm{Al}$ tube sections were heated in air at $1000^{\circ} \mathrm{C}$ for 1 hour with no applied load to form reaction products. $X$-ray diffraction confirmed the presence of $\mathrm{UAl}_{4}, \mathrm{UAl}_{3}, \mathrm{Al}_{2} \mathrm{O}_{3}$, and residual $\mathrm{Al}$; no $\mathrm{U}_{3} \mathrm{O}_{8}$ was found. Specimens were then reheated in the furnace and collapsed at 755 and $660^{\circ} \mathrm{C}$ with 2 and 9 psi average axial stress, respectively. The melting point of $\mathrm{UAl}_{4}$ is $732^{\circ} \mathrm{C}$. 


\section{Tensile Strength}

$\mathrm{U}_{3} \mathrm{O}_{8}-\mathrm{Al}$ tubular sections with $1-1 / 2$ and $31 \mathrm{~b}(0.68$ and $1.36 \mathrm{~kg})$ applied tensile loads failed at 668 and $669^{\circ} \mathrm{C}$, respectively. The average stress in the core was calculated to be 2 and 4 psi. Doubling the applied load had no effect on the failure temperature because the tensile strength of the core is low when the aluminum melts. In fact, in the 1 imit the tensile strength of the specimen should be equal to the surface tension of the molten aluminum metal unless effected by an interlocking oxide network. Because the failure occurred at low stress near the aluminum melting point, it is however concluded that the influence of the oxide structure on the tensile strength is relatively small.

\section{Large-Scale Test}

The strength of the cermet core is low above the melting point of aluminum. To determine if the weight of the tube would cause it to collapse, an 18 inch long section of the three-tube assembly shown in Figure 1 was heated in a $1000^{\circ} \mathrm{C}$ preheated furnace. The calculated axial stress at the bottom of the tubes was about 2.5 psi, assuming only the aluminum cladding melted and ran off the sections. The 2.5 psi stress corresponded to the static failure load at about $917^{\circ} \mathrm{C}$.

The time-temperature curves for the specimens were similar to previously reported curves except the assemblies in the center of the array heated more slowly. At about $985^{\circ} \mathrm{C}$, the exothermic reaction was detected. The peak temperature recorded was about $1400^{\circ} \mathrm{C}$ for the 57 wt \% tube. There was no sighthole to observe the tubes so the furnace was shut down and the door opened. The tubes had collapsed as shown in Figure 8 .

For water cooled assemblies, stresses are present from a frictional surface drag due to the flow of coolant over the surfaces as well as from the weight of the tube. In a low temperature reactor operating at near atmospheric pressure, two phase flow will develop at about 130 to $150^{\circ} \mathrm{C}$ and the surface temperature of the tube will increase rapidly. The flow instability will decrease the frictional drag but pressure surges will develop, producing vibration and high cyclic stresses until tube failure.

Subcooled burnout tests have been carried out at the Savannah River Laboratory using 1 -inch diameter tubes containing 55 wt \% depleted $\mathrm{U}_{3} \mathrm{O}_{8}$-aluminum and $35 \mathrm{wt} \%$ depleted uranium-aluminum alloy cores. The tubes were electrically heated in the laboratory under pool-boiling conditions. The burnout tests were made to compare the time-temperature history and microstructures of alloy and cermet tubes. Photographs of tubes after the burnout tests are shown in Figure 9. 
Particles from the melted region were identified as containing $\mathrm{UAl}_{3}$ and fine eutectic regions of high uranium content. This suggested that the temperature for the alloy core was between 730 and $900^{\circ} \mathrm{C}$. Similar temperatures were reached by cermet tubes; however, no evidence of a thermite reaction was observed. The particles produced were granular in shape and ranged in size from about 1 to $240 \mathrm{mils}(0.03$ to $6.1 \mathrm{~mm})$ with an average size of $50 \mathrm{mils}(1.3 \mathrm{~mm})$.

\section{CONCLUSIONS}

- Test results using 53 wt \% pellets and aluminum-clad fuel elements are consistent with reported data indicating no violent reactions.

- Fuel tubes with $\mathrm{U}_{3} \mathrm{O}_{8}-\mathrm{Al} \mathrm{P} / \mathrm{M}$ cores are expected to behave similarly to cast U-A1 alloy cores during heating and collapse at about $660^{\circ} \mathrm{C}$, the melting point of aluminum, because the strength of $\mathrm{P} / \mathrm{M}$ cores at $660^{\circ} \mathrm{C}$ is low and much higher stresses are expected to develop in the reactor due to the combination of the weight of the tube, the coolant frictional drag forces, and/or pressure surges.

- Heat from a thermite reaction is not an important energy source for reactor fuel tubes with 45 to 57 wt $\% \mathrm{U}_{3} \mathrm{O}_{8}$-aluminum cores. This observation is consistent with recent published data.

- The maximum heat released from a $20 \mathrm{~kg} \mathrm{U} \mathrm{U}_{3} \mathrm{O}_{8}$-aluminum assembly, assuming no dilution from the cladding and a 53 wt $\% \mathrm{U}_{3} \mathrm{O}_{8}$ core, would be about the same as the nuclear decay heat produced by the 540 MWD assembly 30 seconds after shutdown.

- Large-scale tests indicate essentially no effect on the maximum temperature due to the increase in mass or quantity of $\mathrm{U}_{3} \mathrm{O}_{8}$. 
1. R. W. Knight, J. Binns, and G. M. Adamson, Jr., Fabrication Procedures for Manufacturing High Flux Isotope Reactor Fuel Elements, ORNL 4242 (June 1968).

2. L. R. Aronin and A. L. Geary, Hot Extrusion of Metal Powders, NMI-IJ-29 (August 9, 1960).

3. J. D. Fleming and J. W. Johnson, Aluminum- $\mathrm{U}_{3} \mathrm{O}_{8}$ Exothermic Reactions, Nucleonics, 21(5), pp 84-87 (1963).

4. F. T. Bin Ford, The Oak Ridge Research Reactor - Safety Analysis - Vo1. 2, Suppl. 1, Tech. Report No. ORNL-4169/V2/S1 (May 1978).

5. G. Ondracek and E. Patrassi, The Unstable Cermet Combination $\mathrm{U}_{3} \mathrm{O}_{8}$ and Aluminum, II: The Reactivity and Properties of $\mathrm{O}_{3} \mathrm{O}_{8}$-A1 Cermets, Berichte der Deutschen Keramischen Gesel1schaft, Band 45 (1968), Heft 12, Seite, pp 617-621. (In Ger.)

6. L. Baker, J. D. Bingle, R. Warchal and C. Barnes, Aluminum$\mathrm{O}_{3} \mathrm{O}_{8}$ Thermite Reaction, ANL 6800; pp 390-402 (1964).

7. R. 0 . Ivins and F. J. Testa, Studies with Aluminum- $\mathrm{U}_{3} \mathrm{O}_{8}$ Cermet Fuel (HFIR) in TREAT, ANL 7125, PP 163-170 (1966).

8. A. E. Pasto, G. L. Copeland, and M. M. Martin, Quantitative Differential Thermal Analysis Study of the $\mathrm{U}_{3} \mathrm{O}_{8}-\mathrm{Al}$ Thermite Reaction, Ceramic Bulletin, Vol 61, No. 4, pp 491-496 (1982).

9. L. W. Gray, Unexpected Meltdown of Scrap Uranium-Aluminum Cermet Cores During Outgassing, Nuclear Safety, 1564 (1974).

10. E. F. Sturcken, SEM and XES in High Beta-Gamma Radiation Fields, Proceedings of the 9 th Annual Scanning Electron Microscope Symposium, IIT Research Institute, Chicago, Illinois, USA, pp 247-256 (April 1976). 
TABLE 1

Particle Size Distributions of Aluminum and $\mathrm{U}_{3} \mathrm{O}_{8}$ Powders

Particle Size

Weight, $\%$

Range, $\mu \mathrm{m}$

Aluminum Pellets Tubes

$105-149$

$15 \quad 25$

$88-105$

74-88

$0-5$

15

20

15

14

53-74

44-53

$10-25$

15

10

15

3

$<44$

$75-90$

25

28

TABLE 2

Tube Diameters for the Three-Tube Assembly

\begin{tabular}{|c|c|c|}
\hline \multirow[b]{2}{*}{ Fuel Tube } & \multicolumn{2}{|c|}{ Diameter*, inches $(\mathrm{cm})$} \\
\hline & Outer & Inner \\
\hline Outer & $3.700(9.398)$ & $3.434(8.722)$ \\
\hline Middle & $2.936(7.457)$ & $2.590(6.579)$ \\
\hline Inner & $2.048(5.293)$ & $1.718(4.364)$ \\
\hline
\end{tabular}

* $0.030(0.076)$ inch cladding on tube surfaces. 
TABLE 3

Average Axial Compressive Stress and Temperature to Collapse

53 wt $\% \mathrm{U}_{3} \mathrm{O}_{8}-\mathrm{Al}$ and 35 wt $\% \mathrm{U}-\mathrm{Al}$ Outer Tubes in Air

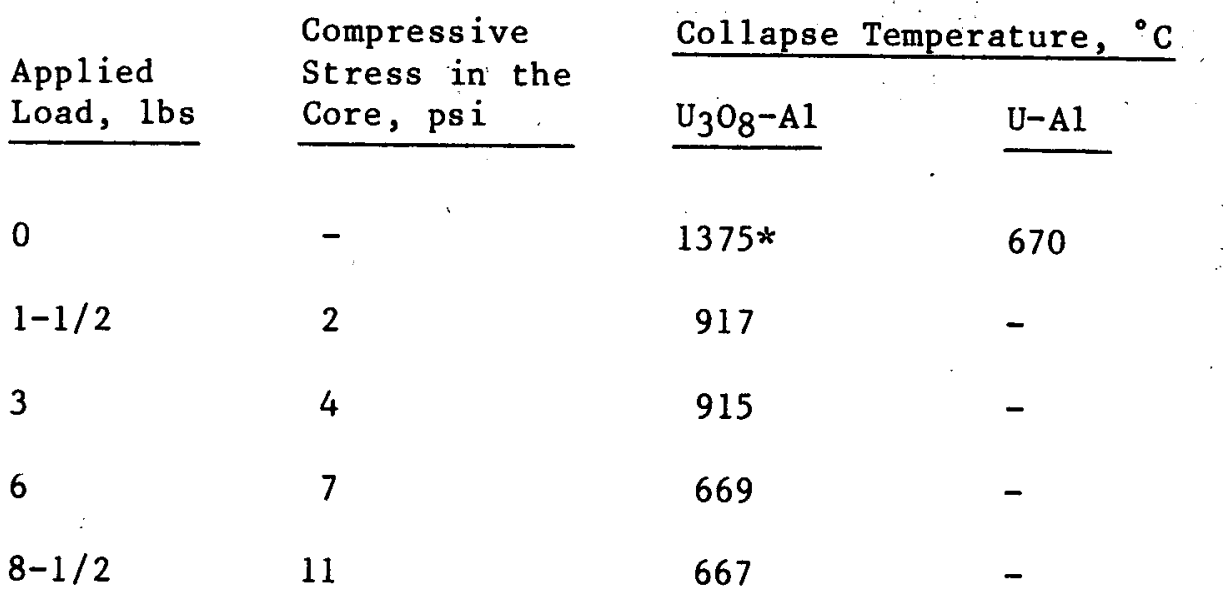

* Collapsed when removed from furnace. 


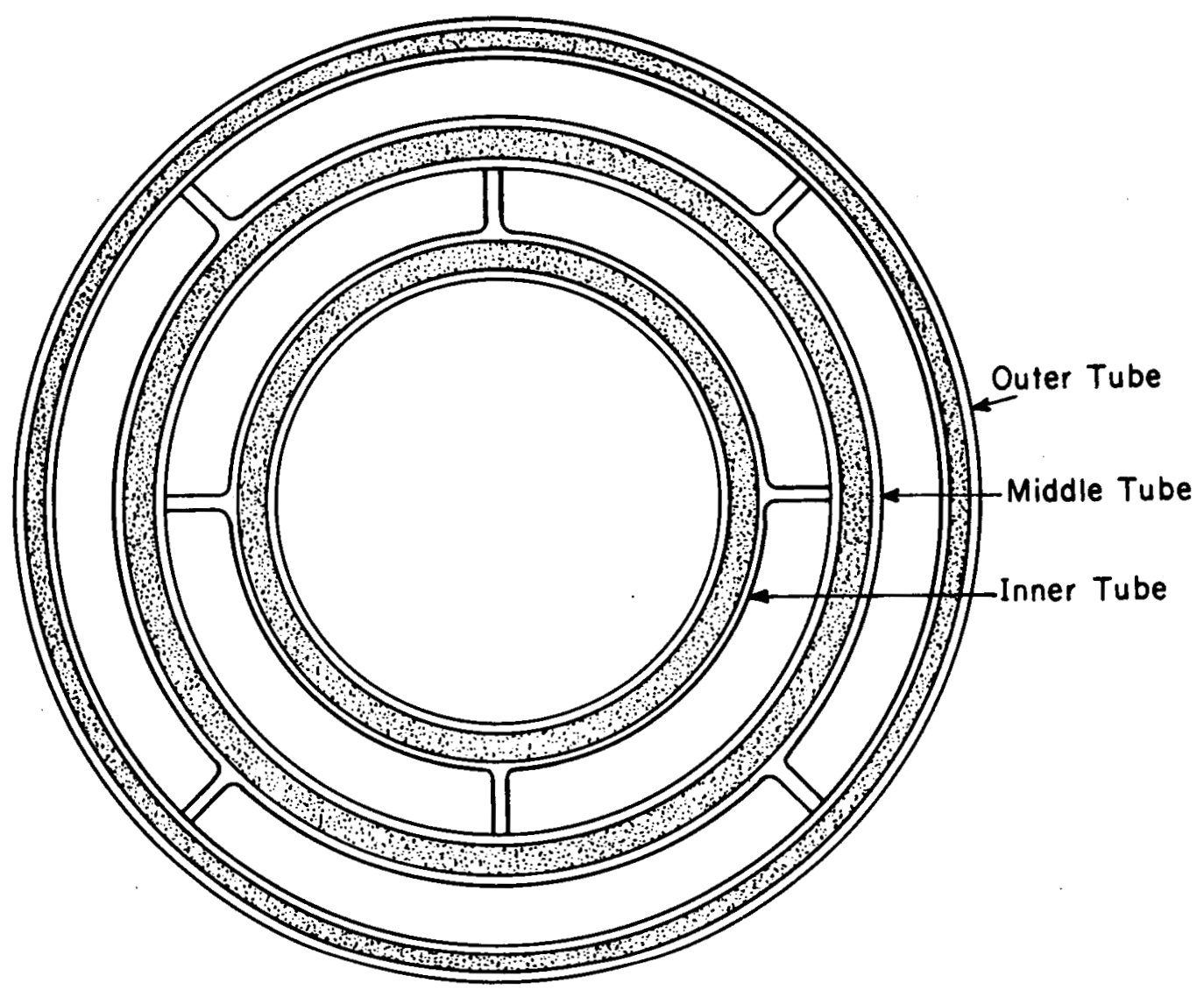

FIGURE 1. Fuel Tube Cross Sections 


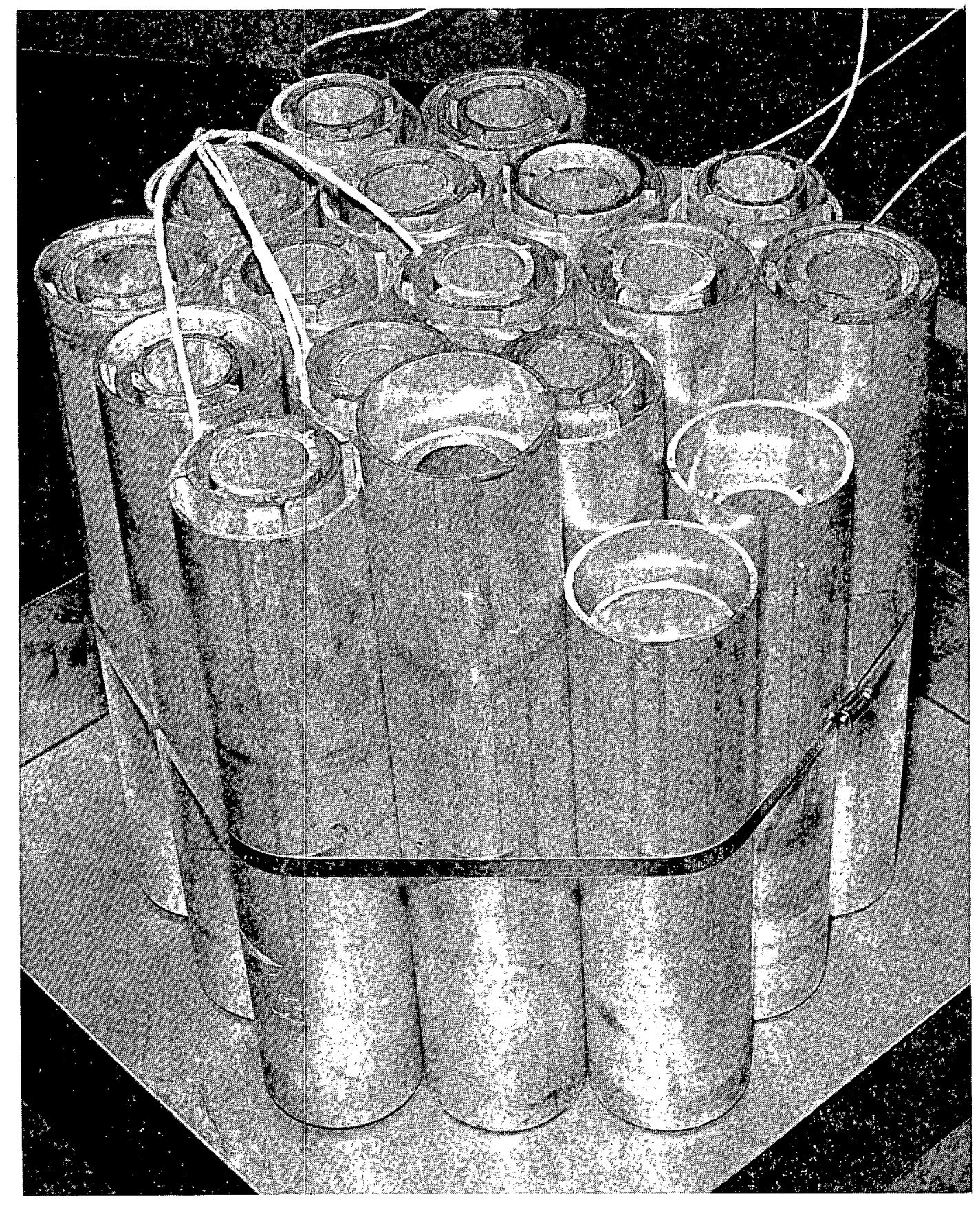

FIGURE 2. Array of 19 Assembled Tube Sections 


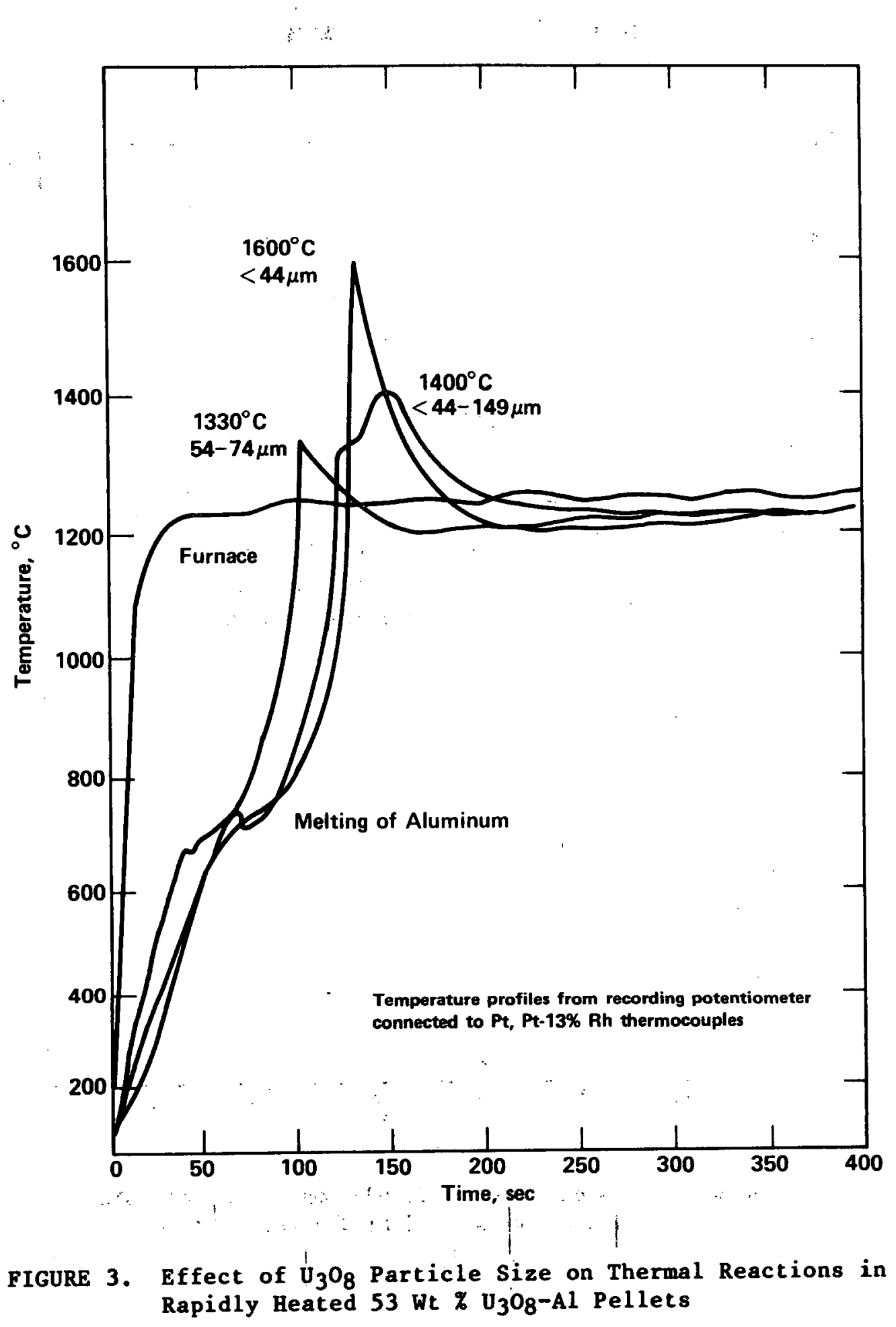




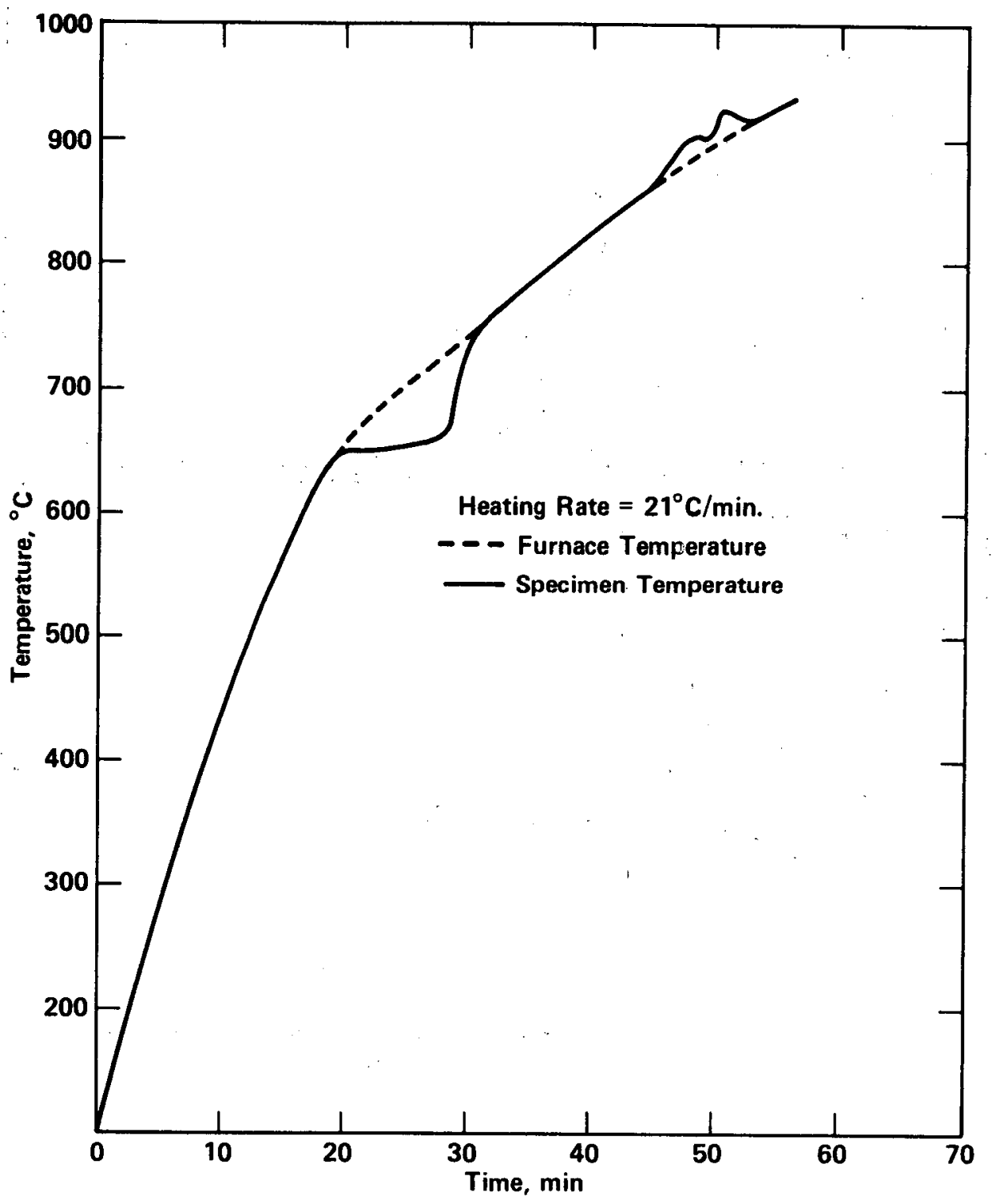

FIGURE 4. Temperature of Slowly Heated Outer Tube Section with a $53 \mathrm{Wt} \% \mathrm{U}_{3} \mathrm{O}_{8}-\mathrm{Al}$ Core 


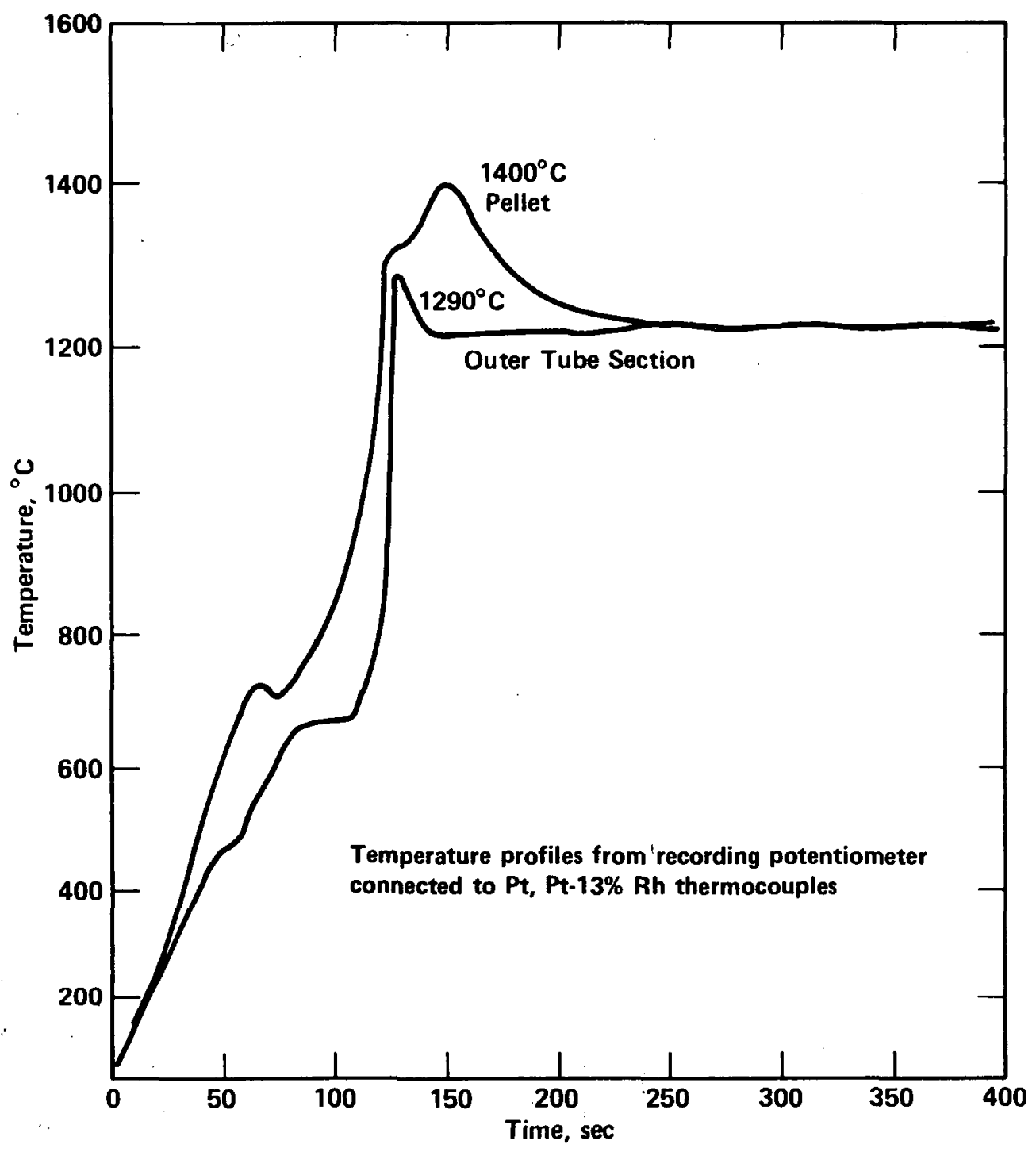

FIGURE 5. Comparison Between Time-Temperature Curves for a 53 Wt $\% \mathrm{O}_{3} \mathrm{O}_{8}-\mathrm{Al}$ Pellet and an Outer Tube Section Plunged into a Preheated Furnace 


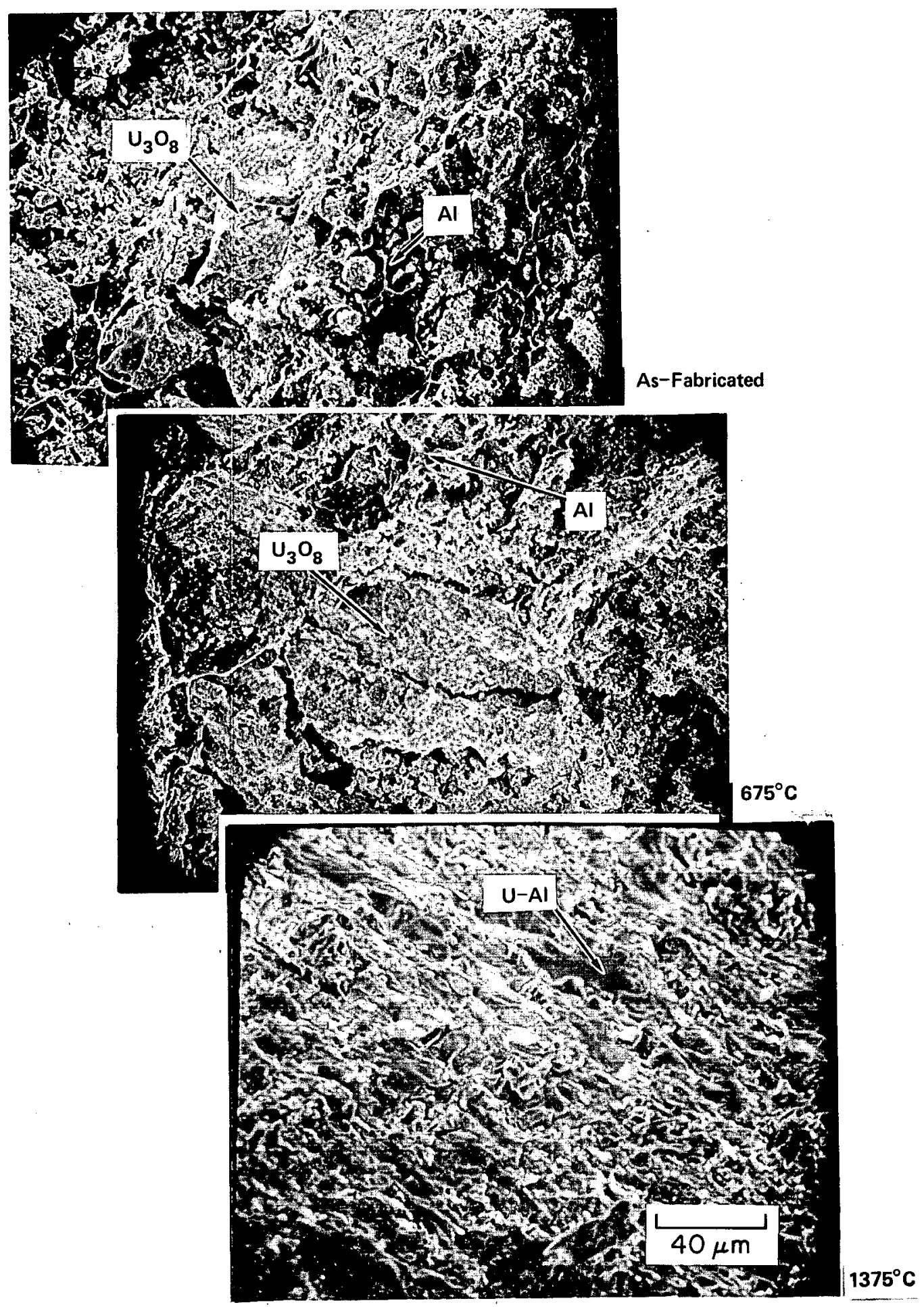

FIGURE 6. Scanning Electron Photomicrographe at 500X of As-Fabricated and Heated $\mathrm{U}_{3} \mathrm{O}_{8}-\mathrm{Al}$ Melt Test Specimens. 


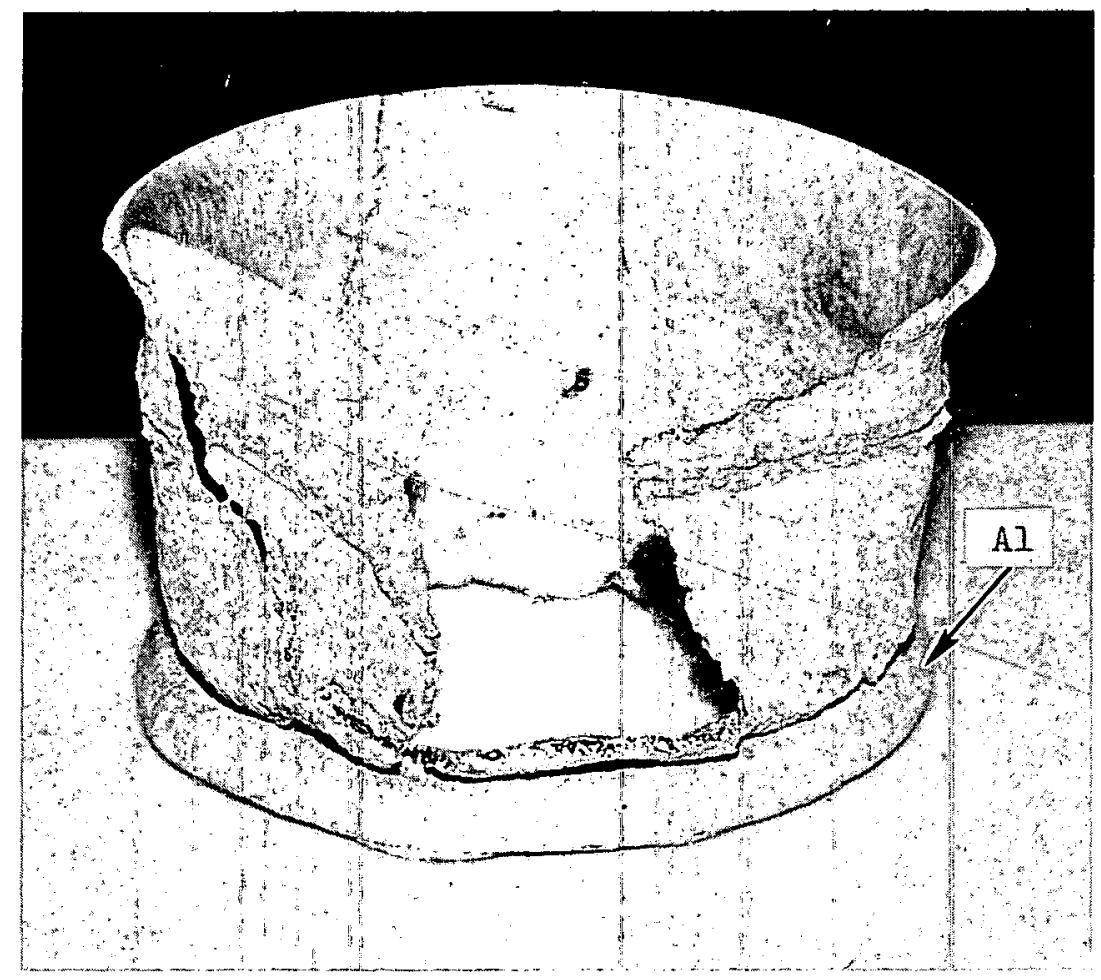

FIGURE 7. U.308-Al Outer Tube Section Rapidly Heated to $1375^{\circ} \mathrm{C}$ 


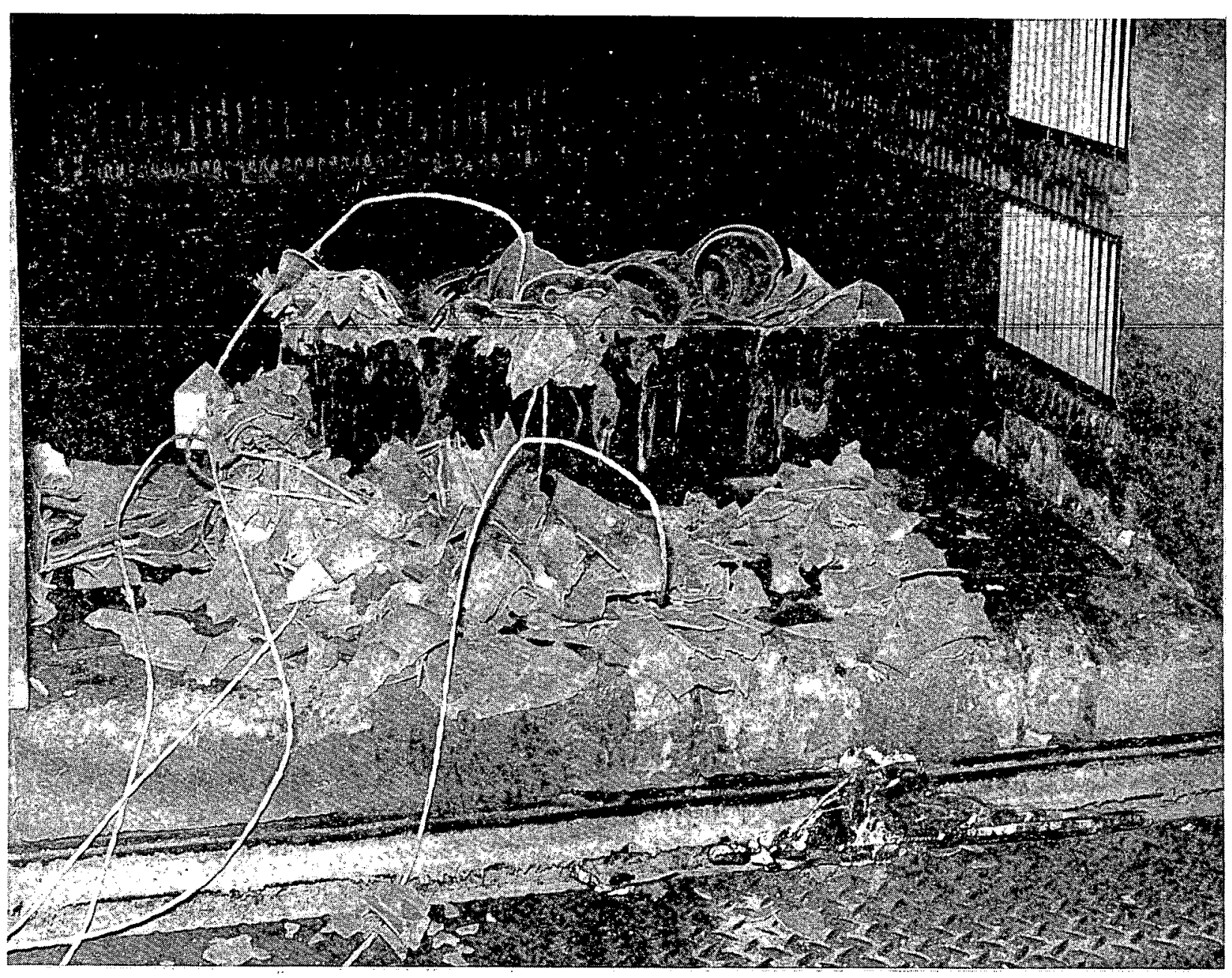

FIGURE 8. Collapsed $\mathrm{U}_{3} \mathrm{O}_{8}-\mathrm{Al}$ Tubes in $1000^{\circ} \mathrm{C}$ Furnace 


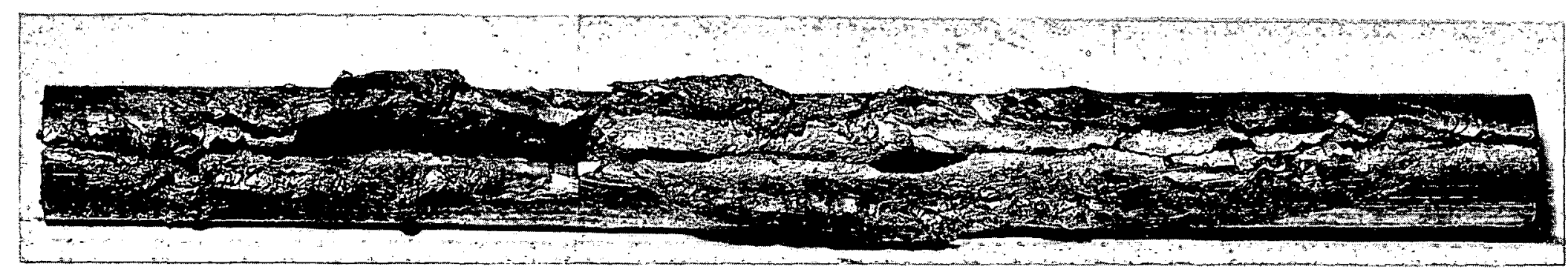

35 wt \% Depleted U-Al Alloy

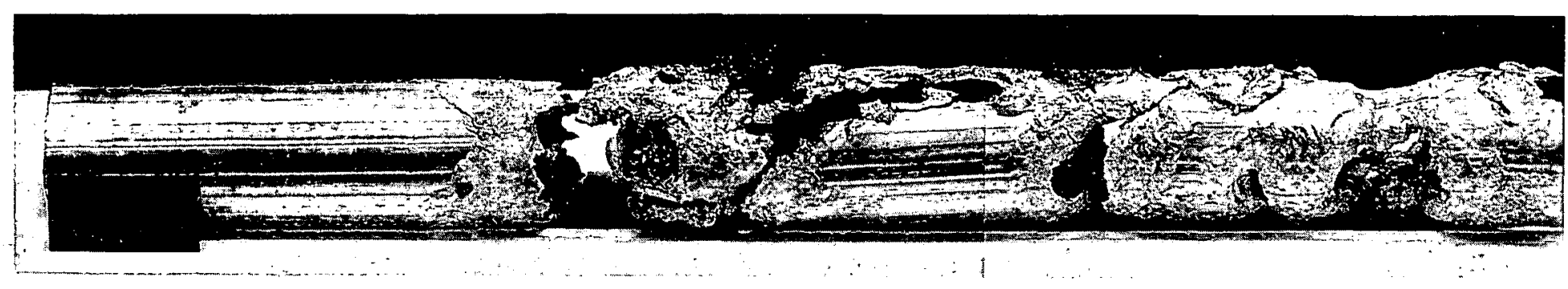

$\sim 55$ wt \% Depleted $\mathrm{U}_{3} \mathrm{O}_{8}-\mathrm{Al}$

FIGURE 9. Photographs $(\sim 1 \mathrm{X})$ of U-Al Alloy and $\mathrm{U}_{3} \mathrm{O}_{8}-\mathrm{Al}$ Cermet Tubes from Burnout Tests 